s. H
379
uss8 Quirber, Thaddeus,

Notes on the Ratural

Afosts of 7 resh water musades 


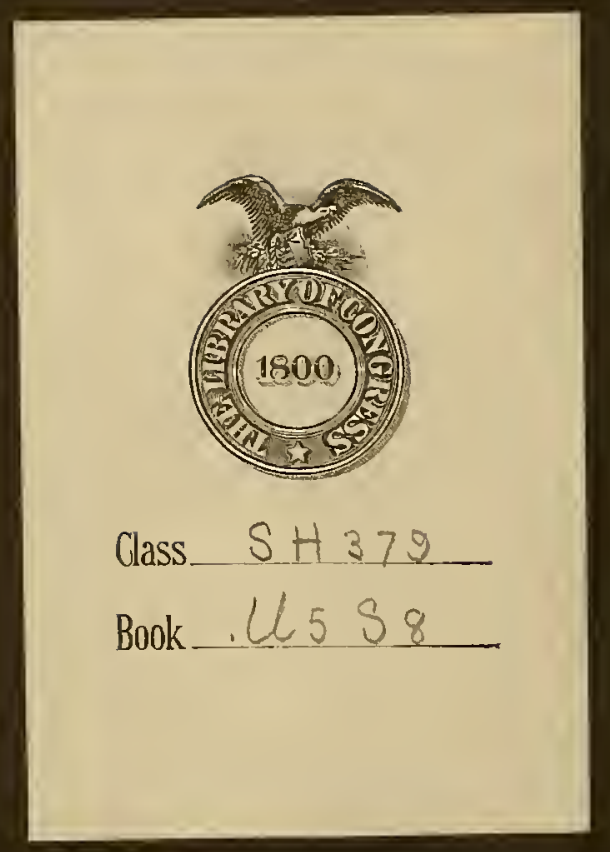




\section{NOTES ON THE NATURAL HOSTS OF FRESH-WATER MUSSELS : : By Thaddeus Surber}

From BULLETIN OF THE BUREAU OF FISHERIES, Volume XXXI, 19I2 Document No. $77^{8}: \because \quad: \quad$ Issued June 28,1913

\footnotetext{
1
}

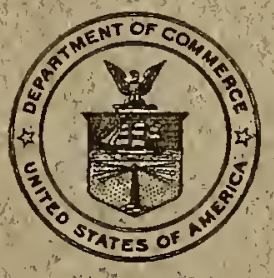

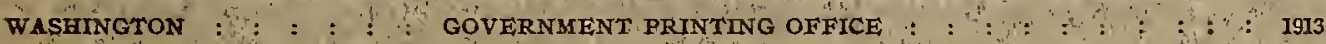





\section{NOTES ON THE NATURAL HOSTS OF FRESH-WATER MUSSELS : : By Thaddeus Surber}

From BULLETIN OF THE BUREAU OF FISHERIES, Volume XXXII, igi 2 Document No. $778:: \quad: \quad: \quad: \quad: \quad: \quad: \quad: \quad:$ Issued June 28,1913

\footnotetext{

}

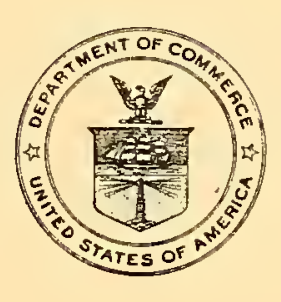

WASHINGTON $: \quad: \quad: \quad: \quad$ GOVERNMENT PRINTING OFFICE $: \quad: \quad: \quad: \quad: \quad: \quad: \quad: 1913$ 
D. OF D.

IUL 91913 
NOTES ON THE NATURAL HOSTS OF FRESH-WATER MUSSELS

*

\author{
By Thaddeus Surber
}

Assistant, United States Biological Laboratory, Fairport, Iowa 
1

1 


\title{
NOTES ON THE NATURAL HOSTS OF FRESH-WATER MUSSELS.
}

\author{
* \\ By THADDEUS SURBER, \\ Assistant, United States Biological Laboratory, Fairport, Iowa.
}

2

A study of the conditions pertaining to natural infection of fishes with the larvæ of fresh-water mussels was begun by the writer, under the direction of Dr. R. E. Coker, at the Fairport laboratory in 1910 , but was interrupted by assignment to other work, and, while an effort was made to resume the study in I91 I, but little was done owing to more pressing duty demanding the time. From the last week in June till the close of November, 1912, however, work was pushed rapidly, 2,815 fish being critically examined, and considerable knowledge gained in regard to certain mussel species.

The observations given in this paper indicate that the natural hosts of our freshwater mussels are divisible into two classes-i. e., specific distributors of particular species, and accidental or occasional hosts. To the first class belong the skipjack (Pomolobus chrysochloris), distributor of the niggerhead (Quadrula ebena); the sheepshead (A plodinotus grunniens), distributor of the paper-shell (Lampsilis lavissima) and the deer-toe (L. donaciformis); and the shovel-nose sturgeon (Scaphirhynchus platorhynchus), distributor of the slough sand-shell (L. fallaciosa). The sauger (Stizostedion canadense) may belong here as distributor of another sand-shell (L. higginsi), but it would be unwise to conclude this on the strength of a single specimen. To the second class, in order of their importance, belong the crappie (Pomoxis anmularis), which has been observed to carry six species; the sauger, carrying four species; two sunfishes (A pomotis cyanellus and Lepomis pallidus) each carrying three; the strawberry bass (Pomoxis sparoides), two species; and another sunfish (Lepomis humilis) and the white bass (Roccus chrysops), one each. A catfish (A meirus natalis) carries a few glochidia of the Quadrula type, but I have not been able to identify the species, owing to accidental loss of material.

Upon consideration, the first class (specific distributors) will be found to agree closely in geographical range with the species of which it is the host, as might be expected. This, of course, is not an original theory, but was advanced years ago by Simpson, ${ }^{a}$ and I am convinced that he was right in his conjecture, and to that end shall attempt to show that it is the case in at least three species of our mussels.

The second class of infections, accidental or occasional hosts, need not be taken up systematically at this time. Reference can be made to table II, however, which shows the species and number of fishes that were observed to be infected with the various species of mussels.

a Simpson, Charles T:: The pearly fresh-water mussels of the United States; their habits, enemies, and diseases, with suggestions for their protection. Bulletin U. S. Fish Commission, vol. XvII (1898), p. 282. 


\section{HOSTS THAT ARE SPECIFIC DISTRIBUTORS.}

\section{Sk1PJACK (Pomolobus chrysochloris).}

This beautiful fish, variously known as "skipjack," "herring," and, at New Boston, I11., as "nail-rod," is of rather erratic habits, being abundant at times at certain places along the Mississippi, and at others one of the rarest of fishes. The fishermen at New Boston tell me that at times it is very abundant there, usually in September, but at other times entirely absent. Mr. Will Morris, of Fairport, informs me that a number of years ago while in a flatboat lying off the point of an island in the Mississippi near Lansing, Iowa, he caught these fish nearly as fast as he could pull them aboard, using a common spoon hook. They take live minnows readily also, but the New Boston fishermen tell me are very rarely caught in a trammel net, most of those taken being secured by means of seines, or hook-and-line fishing in the vicinity of the wing dams. Frequenting the most rapid water in the river, particularly that having a rocky, gravelly bottom,

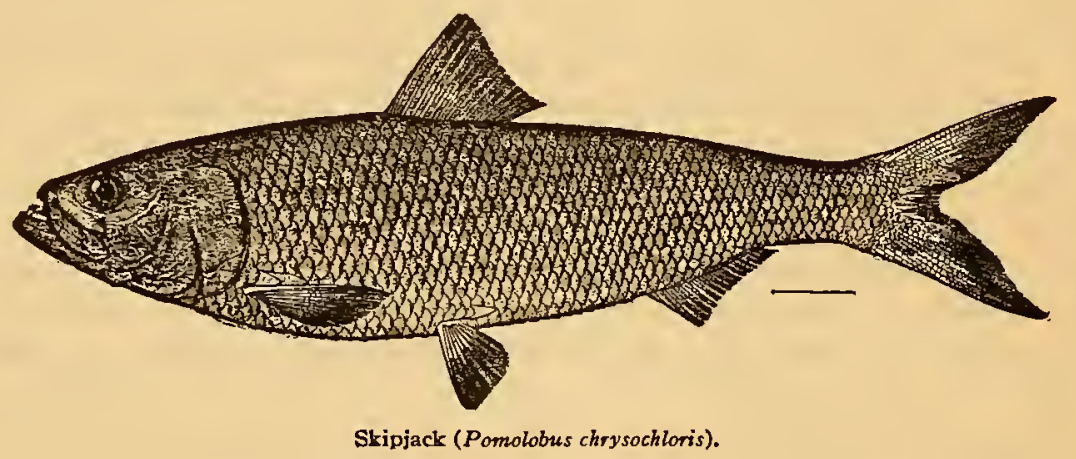

the skipjack is predaceous in habits, feeding mostly on minnows, and Forbes tells us the young feed on insects. I do not believe this fish is nearly so rare as we might infer from Dr. Forbes's records as given in his "Fishes of Illinois," but that the fishermen pay no attention to it at all, considering it a nuisance and immediately throwing overboard all that are caught.

The geographical range of this fish, as given by Jordan and Evermann, is "Mississippi Valley, etc., abundant and resident in larger streams; introduced into Great Lakes. Also in Gulf of Mexico."

The range of $Q$. ebena as given by Simpson is "Mississippi drainage generally except its western portion; Alabama and Tombigbee Rivers; northeast Texas(?)."

The importance of the skipjack to mussel culturists prompts the hope that it may be possible in the course of time to propagate this fish artificially, and in the meantime it is suggested to those who believe in the introduction of western forms into eastern waters to try one of its eastern congeners, $P$. pseudoharengus or $P$. cestivalis as an experimental host for this desirable mussel. The introduction of mussels into other waters by 
transportation of the infected fish, entirely feasible with some fish, ${ }^{a}$ would not be possible in this case, as the skipjack is very delicate and will not admit of handling during the warm summer months.

\section{SHEEPSHEAD (A plodinotus grunniens).}

From its feeding habits we should expect to find this fish more often infected than any other species. In writing of it Dr. Forbes ${ }^{b}$ says:

This fish is of a sluggish habit, living on the bottom of muddy waters, where it feeds especially on mollusks, the shells first being crushed by the powerful, paved millstone-like, pharyngeal jaws. Often the stomach contains only the soft bodies and opercula of gastropod mollusks, the crushed shells having been thrown out. Crawfishes are also sometimes found in the food. Half-grown specimens feed largely on aquatic insects, especially the larvæ of May-flies, mingling larger and larger proportions of mollusks with this food as they increase in size, until they come finally to depend almost wholly upon water snails and the relatively thin-shelled clams.

As it is known to be the specific host for both L. lavissima and $P$. donaciformis, it is of rather more than usual interest. ${ }^{c}$ It can no doubt readily crush the papery shells of levissima, and, from their small size, swallow entire the shells of donaciformis, from which we can readily understand the enormous numbers that are attached to the gills of this fish.

The geographical range of the fish is given as "Great Lakes to Texas and Georgia; abundant in all lakes and large streams west of the Alleghanies and east of the plains" (Jordan and Evermann).

Simpson gives the ranges of the two mussels as follows:

L. lavissima: "Mississippi drainage generally; eastern Texas, southern Michigan, western New York."

"Dr. Ortmann, in an interesting article in a recent issue of "The Nautifus" (vol. xxvr, p. 5r), records the accidental intro duction of the "pocketbook" (L. ventricosa) into the upper Potomac drainage in Maryland and West Virginia.

$b$ Forbes, S. A.: Fishes of Iflinois, Natural History Survey of Illinois, State I ahoratory of Naturai History, vol. Irr, p. 324.

c Since the above was written the author has had the opportunity to examine a number of fish taken by him in White and Cache rivers near Cfarendon, Arkansas. During the first hall of January (1913) I8 specimens of A plodinotus grunniens were secured, eight of which bore naturaf infections, and from the number of giochidia borne by each fish I should accept it as the specific bost of Lampsilis (Proptero) purpurata; five examples were inlected on the gills and another both on gills and caudai fin. The cysts are very farge and consequently very noticeable. While alf are not of the same development the growth in the majority of cases is very marked; the infant mussels have assumed about the development indicated in the figure of lavissime shown in figure 2, plate $\mathrm{XxIX}$. It is presumed these fish became infected some time during the autumn, but as many gravid mussels of this species, all with active glochidia, were taken during January, some may have hecome infected more recently. In these infections the numher of inlant mussels borne hy individual fish varied from 68 to as many as 500 in two cases. The glochidium of purpurala resembles very cfosely that of $L$. (Proptera) alata hoth in shape and size, measuring 0.200 by $0.360 \mathrm{~mm}$; the hooks, however, are hetter developed than in alata.

A stifl more interesting discovery is the finding of a number of glochidia of Quadrula heros, heavily encysted and of considerable development, on the fins of two of these Aplodinotus. This giochidium heing of the hookjess type it was naturally supposed to be a gill parasite, but this does not seem to be the case, as none were found on the gills of the fish.

In the White River materiaf is afso a specimen of tock bass (A mbloplites rupestris) carrying on its gills six glochidia of A rcidens comfrogosa beautifully encysted and of considerable development. The hooked glochidium of Arcidens is closefy related, in form at least, to the A nodonta group, one species of which (catorocta), according to Lefevre and Curtis (Bulfetin U. S. Bureau of Fisheries, vol. $\mathrm{xxx}$, p. $\times 58$ ), would not metamorphose on the gilis ol the carp. A crappie ( $P$. annularis) was also secured bearing the same species on the gilis; but this mussel is probably more frequentiy found on the fins of fishes, as two hickory shad ( $D$ orosoma cepedianum) were taken bearing considerable numbers on the fin margins, particularly the caudal, where they are deeply embedded in the epithelium. 
P. donaciformis: "Mississippi drainage generally; Alabama River area; southwest to the Trinity River, Tex.; Michigan."

In artificial infections this fish takes readily almost any glochidia of the Lampsilis group, but with indifferent results, more probably due to the difficulty of handling it in hot weather than from any other cause.

\section{SHOVEL-NOSE STURgeon (Scaphirhynchus platorhynchus).}

Sturgeons as a rule are bottom feeders, and this species is no exception, so that we should expect to find it very frequently infected. Such, however, does not seem to be the case. The heavy gill filaments of this fish render difficult the detection of glochidia; therefore all that were obtainable were carefully gone over, and it is not believed any were overlooked which were carrying larvæ in any numbers. On October 15 and again on November 7 specimens were taken holding larvæ of Lampsilis fallaciosa, and these were in sufficient numbers to indicate that it is the specific host of this particular species.

While it is unsafe probably to consider this fish the only distributor of fallaciosa, it is interesting to note the known geographical ranges of the two species, which is as follows:

S. platorhynchus: "Mississippi Valley and streams of the Western and Southern States" (Jordan \& Evermann).

L. fallaciosa: "Upper Mississippi drainage; south to the Cumberland River, Tennessee, and to Arkansas; Red River of the North?" (Simpson).

\section{MUSSELS AS PARASITES.}

We shall now consider the matter from another point of view, taking up in their order the various mussel species as parasites. It will be noted that all species considered in this study are gill parasites with one exception, A. corpulenta, and consequently nearly all of commercial value.

\section{SLOP-BUCKET (Anodonta corpulenta).}

But one fish has been taken bearing larvæ on the external parts, and this is found to be corpulenta. On November 10, 1910, along the river shore within the grounds of the biological station, a young skipjack about 3 inches in length was picked up which held 24 glochidia, mostly on the caudal fin, but a few on ventrals and pectorals. By reference to the accompanying figure (fig. $\mathrm{x}, \mathrm{pl}$. xxrx) it will be noted that encystment is incomplete, though but a small portion of the dorsal edge of the shell protrudes, and that the infection is quite recent is further shown by the condition of development in the adductor muscle. This glochidium is saddled over the edge of the caudal fin and grasps two of the cartilaginous rays up almost to the adductor muscle; the other glochidia occupied relatively the same positions on the fins as shown in this figure. 
YeLLOW SAND-SHELL (Lampsilis anodontoides).

During the latter part of June and early in July this mussel was found on the two species of crappie and on Apomotis cyanellus and Lepomis humilis, but in such limited numbers that it is extremely doubtful if any of these fish are the actual host, as the greatest number occurring on any one species was six. As this time is the height of the spawning season of this particular mussel, and all the infections were recent, it is presumed they were more or less accidental.

Some sunfish infected artificially with glochidia of this mussel July I, I91 I, apparently took well and were deeply encysted at the end of three and three-fourths hours, but two days later not a single glochidium could be found on any of the fish, due probably to unfavorable conditions. On June 27,1910 , a lot of fish, chiefly Pomoxis and Lepomis, with a few Micropterus, Aplodinotus, and Roccus were infected and apparently took well, but the glochidia never completed their metamorphosis. However, on August II, 1910, a few metamorphosed on a sunfish (A.cyanellus) in four days, about I per cent of those encysted.

\section{Slough SAND-Shell, (Lampsilis fallaciosa).}

On June 27 a crappie ( $P$. annularis) was taken holding 16 glochidia of this species, but it was not again found till October 15, when a sturgeon ( $S$. platorhynchus) was taken holding 125. On November 7 another sturgeon was taken holding 56 .

This glochidium does not, as a rule, take very near the tips of the filaments in the sturgeon, but rather deep, a great many as deep as the fork of the filament, and encystment is very heavy. The October infection indicates but very slight development, or none at all; cysts enormous. Examination of the November infection reveals the fact that the adductor muscle is dividing and traces of the foot are clearly discernible. It is believed these sturgeon become infected sometime during September or October, and the metamorphosis would, therefore, not be completed till some time during the following spring.

\section{Higgins SAND-SHELL (Lampsilis higginsi).}

The only fish so far taken which unquestionably holds this glochidium is a specimen of Stizostedion canadense taken October 4, 1912; it holds approximately 600 glochidia. The infection was recent and no development is clearly indicated; cysts very heavy.

\section{PAPER-SHELI, (Lampsilis lavissima).}

For the past three years we have been taking sheepshead (Aplodinotus grunniens) bearing enormous numbers of young lavissima, generally in a high state of development. The sheepshead, from its habits, should be expected to be found more frequently infected than most any other species of fish, yet the percentage of infected fish is small.

Only 2 per cent of the fish taken during the period from June to November were infected with this larva, the number carried by each fish varying from 112 to 850 . It was hoped that a critical study of the material would indicate the period of parasitism, but such is not the case, though I am of opinion that it covers a period of nearly a year.

$$
89967^{\circ}-13-2
$$


The only fish so far taken carrying what is apparently recent infection is one taken October $2 \mathrm{I}$, but only a few, about $\mathrm{I}$ per cent, are of this stage, i. e., the glochidium still simple. The next stage is indicated in specimens secured October 15 , where the growth is quite decided, the infant mussel having assumed a nearly circular form when viewed from the side; this phase is clearly shown in figures 2 (side view) and 3 (postero or antero ventral view). In figure 2 the larval mussel is on the extreme tip of the gill filament, while figure 3 is encysted about $3 \mathrm{~mm}$. back from the tip and on the flat side of the filament. Another fish, taken October 30 , holds larval mussels in a more uniform state of development, of a stage clearly shown by figure 4 ; by reference to this figure it will be found that the young mussel has apparently grown more rapidly in length than in height, and that in the region of the umbones, both anteriorly and posteriorly, it has not grown at all, except in thickness, giving it a curions depressed effect there. Figure 4 exhibits the sharpness of the ventral points of the glochidial shell on the upper side, caused by the growth of the shell of the young mussel expanding the glochidial shell; in figure 5 a dorsal view is given of another specimen of the same relative development to show increase in thickness.

The greatest development seems to be reached during October, when they have assumed the shape and size indicated in figures 6 and 7 , where it has increased three to four times in length over glochidium and the inflation (thickness) is so marked as to suggest anything but the parent shell, when viewed dorsally (fig. 7). This stage has been shown before (Coker and Surber, Biological Bulletin, vol. 20, p. 179-182, fig. 5, 6 , and 7). It is believed that at this stage the parasitism is completed, or nearly so, and this belief is strengthened by the fact that on November 2 a fish was taken holding comparatively few (I20) mussels and a number of ruptured cysts which had probably held others a very short time previously, though it is of course possible that the ruptures may have been caused by other parasites, but this is not deemed probable. We might infer from this that the fish became infected either the preceding spring (I912) or during September of the preceding year (I9II), the latter seeming the more probable. Lavissima with ripe glochidia has been taken in the vicinity of Fairport during April, June, and September.

So far, this mussel has been found on but one other species of fish, the crappie, in which the same development is indicated as occurs in the sheepshead.

TABle I.-Number of Larval, I. L,ävissima Carried by the Host.

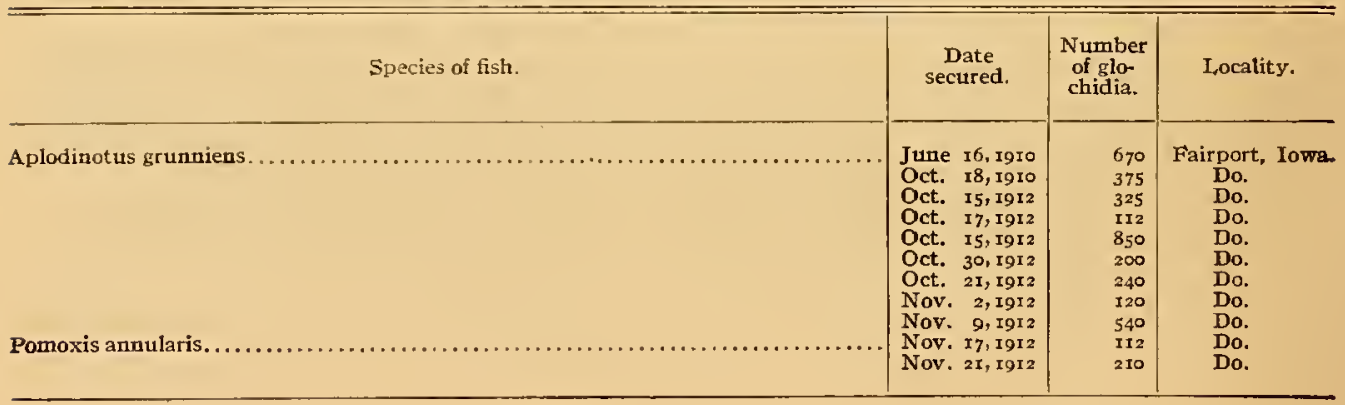


Mucket (Lampsilis ligamentina).

On the 26th of September a rather large Roccus chrysops was taken holding upward of 200 glochidia of this species; cysts are heavy but glochidia show no development at all, so that it is presumed to be a recent infection.

A great many other fish were taken during September and October, principally crappie and sunfish, infected with this mussel, but as the crew of the station were at work infecting and liberating fish with this larva, all were presumed to be artificial infections. No Roccus had been artificially infected previous to September $\mathbf{2 6}$, so that the above record is deemed permissible.

\section{BL,ACK SAND-SHELL, (Lampsilis recta).}

The only time this mussel has been found a natural parasite was July 2, I9I2, when a Lepomis pallidus was taken bearing 35 glochidia. The infection was recent, deeply encysted, and I have no doubt would have metamorphosed in a very short time, the fish being extremely strong and robust.

\section{DEER-TOE (Plagiola donaciformis).}

This small mussel, so far, seems to be found almost exclusively on the sheepshead, the only exception being a sauger taken quite recently. Discovered first at New Boston, I11., in August, 1910, it has since been found at frequent intervals, both there and at Fairport.

The number of young mussels found on a fish varies considerably, but is usually great, a fish taken October 30 holding about 2,800 , which is the greatest number found. The duration of parasitism is problematical; no fish have been found recently infected, all infections so far found being highly developed. As we have secured gravid mussels of this species with fully developed glochidia only during the latter part of July, it seems probable, and is possible, that the enormous development indicated occurs in the short space of two months, but this of course can only be proved by artificial infection of the specific host. Specimens of least development, so far known, are some taken July 20,1911 , one of which is shown in figure 8 (postero-dorsal view); this would indicate one of two facts, either that it was an infection of the previous year, in which case growth is comparatively slow, or that it was very recent and growth correspondingly rapid. On a fish taken August i6 occur I,495 young mussels, the development of which is very great, far exceeding that shown previously in laevissima; one in side view is shown by figure 9 , which is found to have increased seven times in length, and about three and one-half times in depth over glochidial shell, yet all on this fish were not uniformly developed, as is shown in figure ro $(a)$. Figure ro shows a portion of a filament with young mussels in situ, two of which are on the edge, while the other (a) is encysted on the flat side of the filament. 
TABLE II.-NUMBER OF LARVAL, P. DONACIFORMIS CARRIED BX THE HOST.

\begin{tabular}{|c|c|c|c|}
\hline Species of fish. & $\begin{array}{c}\text { Date } \\
\text { secured. }\end{array}$ & $\begin{array}{l}\text { Number } \\
\text { of glo- } \\
\text { chidia. }\end{array}$ & Locality. \\
\hline Stizostedion canadense... & 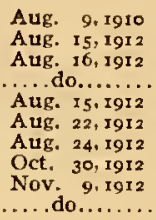 & $\begin{array}{r}\mathrm{I}, 100 \\
300 \\
\mathrm{r}, 495 \\
\mathrm{I}, 200 \\
76 \\
2 \\
280 \\
2,800 \\
1,000 \\
1,800\end{array}$ & $\begin{array}{l}\text { New Boston, Ill. } \\
\text { Do. } \\
\text { Do. } \\
\text { Do. } \\
\text { Do. } \\
\text { Fairport, Iowa. } \\
\text { Do. } \\
\text { Do. } \\
\text { Do. } \\
\text { Do. }\end{array}$ \\
\hline
\end{tabular}

ButTERFLy (Plagiola securis).

But a single glochidium, well encysted, has been found by the writer, this being found on a sunfish (A pomotis cyanellus) taken July I, I912; no development was indicated.

Experiments in artificial infection of the black bass, crappie, sunfish, and catfish with this larva have proved unfavorable, so that we must conclude the specific host is as yet unknown.

\section{BUllHEAD, SHEEPNOSE (Pleurobema asopa).}

A sauger (S. canadense) was taken July 20, 1911, holding I 7 glochidia of this mussel. As the anterior and posterior adductor muscles were clearly defined and the foot more or less conspicuous, indications are that this fish is at least an occasional host of this larva. As the mussel itself is not at all common, the sauger may eventually prove to be the specific host. An infection is shown in figure 17 .

\section{NIGGERHEAD (Quadrula ebena).}

The discovery of the specific host of this mussel on August 13, 1912, was a great gratification, occurring as it did after almost three years' experimentation. Repeated failures in obtaining artificial infections with all the species of fish obtainable in the vicinity of Fairport led me to search for fish not previously taken, of which the skipjack ( $P$. chrysochloris) was about the only one remaining. The taking of a specimen of this fish, June 18, 1910, by $\mathrm{H}$. Walton Clark, was overlooked till after the August, 1912, material was identified, when his note was looked up and later the fish itself secured and found to be heavily infected. Mr. Clark, while recognizing at the time of taking that his r9Io specimen was carrying glochidia in great numbers, was unable to identify the species of mussel owing to lack of material, no glochidia of $Q$. ebena being available at that time for comparison. Owing to the great commercial value of this shell, which is exceeded by none, the final discovery of the host is of far-reaching importance.

During the season of 1912, I5 specimens of Pomolobus were secured in the vicinity of Fairport and New Boston, the 5 specimens secured during August all bearing glochidia in large numbers, ranging from $I, 895$ to 3,740 for each fish. During this month little development of the glochidia was shown which would indicate recent infection, but a 
specimen taken at Fairport, September I I, had only 48 glochidia remaining, and two specimens out of a total of nine taken at New Boston, September 24, held 26 and $3 \mathrm{I}$, respectively, all the September material indicating much development. The same results are shown by some material from the upper Mississippi which Mr. W. B. Gorham secured while with the reclamation work of the steamer Curlew, when, on August 26, at La Crosse, Wis., he secured one fish holding 365 glochidia, well along in development, and another fish at Genoa, Wis., September 23, with development about completed. In the vicinity of Fairport ebena has been secured with well-developed embryos during the last week in May and during June, July, and August. This would indicate a comparatively rapid metamorphosis, which, in my opinion at least, does not much, if at all, exceed two months.

A study of the material shows us that ebena undergoes no important increase in size of shell, and consequently no change in form, during metamorphosis. Figure i I shows a glochidium (side view) on the edge of a filament. By reference to the figure it will be noted that considerable development is indicated, the posterior adductor showing in place, and the foot considerably developed; this was taken August I3, and figure I 2 shows dorsal and ventral views of the same development. In the specimens taken September 24 , shown by figure 13 , the development is very clearly defined, the foot having reached what might be considered normal size, while the position of the anterior and posterior adductors and the protractor pedis is distinct; it is believed this young mussel would have left its host in a very short time. In the specimens taken June is, i 910 , practically no development at all has occurred; the distal third of a gill filament of this infection is shown in figure 14 .

Particular attention is called to figures $I_{2}$ and $I_{3}$, where the cysts are shown off to one side of the young mussel, a characteristic feature of those which have attained sufficient development. It seems the young mussel has shifted its position, migrating as it were from its normal position in the cyst to a new one among the delicate filaments, disarranging them as indicated in the figure (12) on the right side; this movement is preliminary to its ultimate freedom. The young mussels are now lying on the surface of the filament beneath the mucous membrane covering it, while the epithelial cells forming the cyst proper remain unbroken, so that it has evidently pushed along beneath the membranaceous covering to its present position, the membrane having now adapted itself to the new conditions and formed, as it were, a new cyst which covers the entire filament and gives to the parasite much increased freedom of movement. This condition is more clearly shown by reference to figure 18 , where the distinctly swollen area comprising the new cyst is accentuated, though the magnification in this figure is much less than indicated in figures 12 or 13 .

In the more recent infections-that is, the young still in the glochidial stage, as shown by figure 14 -this remarkable condition does not exist, the development being such that the animal has no power of locomotion as yet. On the other hand, in specimens taken during September, there are many cysts having the appearance of these shown in figure I3, simple, hollow, globular areas suggesting small tumors, unmistakably the former abode of some young mussel which has completed its metamorphosis and departed with- 
out apparent serious injury to the cyst. This condition is interesting, nothing like it having previously been noted in the parasitism of any of our mussels, so far as I know, and the causes leading up to it will bear careful investigation. This can be done only by a thorough study of the relations existing between host and parasite, in which connection it will be well to study in detail the structure of the gills of the host.

Table III.-Number of Larval Q. ebena Carried by the Host.

\begin{tabular}{|c|c|c|c|}
\hline Species of $\mathbf{6 s h}$. & $\begin{array}{c}\text { Date } \\
\text { secured. }\end{array}$ & $\begin{array}{l}\text { Number } \\
\text { of glo- } \\
\text { chidia. }\end{array}$ & Locality. \\
\hline Pomolobus chrysocbloris.. & 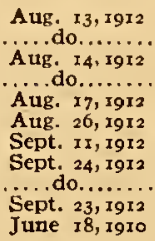 & $\begin{array}{r}2,100 \\
3,740 \\
x, 895 \\
2,700 \\
3,200 \\
365 \\
48 \\
26 \\
31 \\
9 \\
2,570\end{array}$ & $\begin{array}{l}\text { Pearl Slough, Fairport. } \\
\text { Do. } \\
\text { Buttermilk Slough, Fairport. } \\
\text { Upper end Geneva Island. } \\
\text { New Boston, Ill. } \\
\text { La Crosse, Wis. } \\
\text { Fairport, Iowa. } \\
\text { New Booston, Ill. } \\
\text { Do. } \\
\text { Genoa, Wis. } \\
\text { Fairport, Iowa. }\end{array}$ \\
\hline
\end{tabular}

MONKEY-FACE (Quadrula metanevra).

During the early part of July five blue sunfish (Lepomis pallidus) and one green sunfish (A. cyanellus) were taken bearing a comparatively small number of glochidia of this mussel. The two heaviest infections are one of 50 , the other of 69 , and it is therefore probable the sunfishes may be found to be the specific hosts of this mussel. By reference to figure 15 it will be found that one of the infections, taken July 2 , is developing, the adductors having become clearly defined and rudiments of the foot apparent. No change in form nor increase in size of shell is anticipated in this species.

Table IV.-Number of Larval Q. metanevra Carried by the Host.

\begin{tabular}{|c|c|c|c|}
\hline Species of fish. & $\begin{array}{c}\text { Date } \\
\text { secured. }\end{array}$ & $\begin{array}{l}\text { Number } \\
\text { of glo- } \\
\text { chidia. }\end{array}$ & Locality. \\
\hline $\begin{array}{l}\text { Lepomis pallidus } \ldots \ldots \ldots \ldots \ldots \ldots \ldots \\
\text { Apomotis cyanellus............... }\end{array}$ & 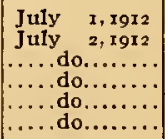 & $\begin{array}{r}6 \\
50 \\
\mathbf{1} \\
6 \\
69 \\
\times 5\end{array}$ & $\begin{array}{l}\text { Fairport, Iowa. } \\
\text { Do. } \\
\text { Do. } \\
\text { Do. } \\
\text { Do. } \\
\text { Do. }\end{array}$ \\
\hline
\end{tabular}

Blue-POINT; THREe-RIDGe (Quadrula plicata).

The only fish so far taken infected with this species was on June 28,1912 , when a sauger (S. canadense) carrying 28 and a crappie ( $P$. annularis) 4 glochidia were secured. The development is decidedly progressing as indicated in figure 16 , where the foot and both adductor muscles are clearly defined. The figure (I6) is a glochidium attached to edge of gill filament of the sauger. 
PIMPLE-BACK (Quadrula pustulata).

But two glochidia of this species have so far been detected and this on a crappie (P. annularis) taken September 12, 1912. While it is rather late in the season to expect to find this mussel still parasitic, it is not believed that the identification is wrong, yet the development should have progressed more rapidly than is the case in this instance.

\section{PIMPLE-BACK (Quadrula pustulosa).}

October seems extremely late to find any Quadrulas persisting, but the gills of a crappie taken the 17 th of that month reveals a single glochidium of what I am compelled to regard as this species. No development whatever is indicated and the presence of the glochidium at this late season may be due to some freak physiological characteristic not easily understood.

\section{QUADRULA SOLIDA.}

Two sunfish (Lepomis pallidus) were taken July 1, 1912, bearing glochidia of this mussel, one having 50 present, the other only 6 . The development is similar to that noted in plicata, the foot and adductors being clearly indicated. The shell itself is not at all common in this region, and one would naturally expect to find few fish infected. The glochidium of this species closely resembles that of ebena and might be mistaken for the latter by a careless observer, but may be recognized by its greater comparative depth and shorter, straighter hinge line.

\section{PIG-TOE (Quadru?a trigona).}

From the frequency with which this shell is found in the vicinity of Fairport, it is surprising more infected fish are not taken, its spawning season being July and August. So far only a single black crappie (Pomoxis sparoides) taken June 25, 1912, has been found infected, and it held but three glochidia, none of which showed any development whatever, thus indicating recent infection.

\section{SUMMARY.}

In conclusion attention is directed to the table of fish examined (table v), following. The remarkably small percentage of fish infected in a state of nature will be apparent at once, even of those species known to carry glochidia, if we except the skipjack (Pomolobus chrysochloris). In the case of the sheepshead, known to be the specific host for two species of mussels, the percentage is about $3 \frac{2}{3}$, while in Pomoxis annularis, which carries more species of mussels than any other fish, it is only seven-tenths of I per cent. Out of a total of 38 species examined, numbering some 2,815 individuals, only 46 fish were infected, but of course only i i species are apparently susceptible to natural infection. Further investigations will reveal much, the work having only begun. A summary of the present known hosts is shown in table vi. 
By reference to table $\mathrm{v}$ the advantages of artificial infection can be readily: imagined when the small percentage found infected in a state of nature is considered. Some one has long ago estimated that in the case of some fishes but ro per cent of the eggs deposited naturally are even fertilized, whereas by artificial means it is now an established fact that fully $9^{\circ}$ per cent, and even better, is not only possible, but a rule, in handling these same fishes. Now in the mussel the eggs are fertilized and the young developed ready for their parasitic life while still in the gills of the parent, so that all man has to do is find the specific host of a given species, procure that host, and load it to the limit, which may exceed the optimum infection of Lefevre and Curtis ${ }^{a}$ in some cases. The simplicity of the proceeding is startling when we consider the ease with which the glochidia can be procured, a fair sized nucket (L. ligamentina), for instance, producing as many as $3,500,000$ young and the niggerhead ( $Q$. ebena) about 350,000 .

Table V.-Fish Caught and Examined for Natural, Infection, June to November, igiz.

\begin{tabular}{|c|c|c|c|c|c|c|c|c|c|c|c|c|}
\hline \multirow{2}{*}{ Species of fisli. } & \multicolumn{2}{|c|}{ June-July. } & \multicolumn{2}{|c|}{ August. } & \multicolumn{2}{|c|}{ September. } & \multicolumn{2}{|c|}{ October. } & \multicolumn{2}{|c|}{ November. } & \multicolumn{2}{|c|}{ Total. } \\
\hline & $\begin{array}{l}\text { Exam. } \\
\text { ined. }\end{array}$ & $\begin{array}{c}\text { In- } \\
\text { fected. }\end{array}$ & $\begin{array}{l}\text { Exam- } \\
\text { ined. }\end{array}$ & $\begin{array}{l}\text { In- } \\
\text { fected. }\end{array}$ & $\begin{array}{l}\text { Exam } \\
\text { ined. }\end{array}$ & $\begin{array}{l}\text { In- } \\
\text { fected. }\end{array}$ & $\begin{array}{l}\text { Exam- } \\
\text { ined. }\end{array}$ & $\begin{array}{l}\text { In- } \\
\text { fetced. }\end{array}$ & $\begin{array}{l}\text { Exam- } \\
\text { ined. }\end{array}$ & $\begin{array}{c}\text { 1n- } \\
\text { fected. }\end{array}$ & $\begin{array}{l}\text { Exam- } \\
\text { ined. }\end{array}$ & $\begin{array}{l}\text { In- } \\
\text { fected. }\end{array}$ \\
\hline I. Petromyzon castaneus & & & & & & & I & & & & I & \\
\hline 2. Petromyzon concolor. & & & 2 & & I & & 2 & & & & 4 & \\
\hline 3. Polyodon spathuia, & & & 3 & & & & & & & & 2 & \\
\hline 4. Scaphirhynchus platorhynchus. . & ... & ... & I3 & $\ldots \ldots$ & 16 & $\cdots \cdots$ & I9 & I & 13 & $\mathbf{I}$ & 65 & \\
\hline 5. Lepisosteus osseus. . . . & $\cdots$ & & & & 7 & & & & & & & \\
\hline 6. Amia calva .......... & $\cdots \cdots+$ & & 2 & $\cdots$ & 2 & & & & 4 & & 8 & \\
\hline 7. Ictalurus furcatus... & …... & …… & $\cdots$ & & 3 & & & & & & 3 & \\
\hline 8. Ictalurus punctatus. . & $\cdots \cdots$ & & 21 & & 43 & & $7^{\circ}$ & & 29 & & 168 & $\cdots \cdots$ \\
\hline $\begin{array}{l}\text { 9. Ameiurus natalis }, \ldots \ldots \ldots \ldots \\
\text { Io. Ameiurus nebulosus } \ldots \ldots \ldots \ldots \text {. }\end{array}$ & & & & & & & & & & & & \\
\hline Io. Ameiurus melas. ................ & & & 4 & & & & 2 & & & & $\begin{array}{l}\mathrm{r} \\
6\end{array}$ & \\
\hline I2. Leptops olivaris............. & & & 44 & & 18 & & 4 & & I & & 67 & \\
\hline I3. Carpiodes carpio.... & .... & & $\ldots$ & $\cdots$ & $\ldots$ & & I & & & & $\mathbf{I}$ & . \\
\hline I 4 . Carpiodes velifer $\ldots \ldots \ldots \ldots \ldots \ldots$ & 18 & & 7 & & & & 3 & & 53 & & $4 \mathrm{I}$ & \\
\hline I5. Cycleptus elongatus $\ldots \ldots \ldots \ldots$. & & & & & & & 2 & & & & $=$ & … \\
\hline I6. Minytrema melanops. . & & & & & & & & & I & & I & \\
\hline 17. Moxostoma breviceps. . & & & I & & & & & & & & $\mathrm{x}$ & \\
\hline toma aureolum.. & .... & & 3 & & & & & & & & 3 & \\
\hline tg. Hiodon alosoides. & & & & $\cdots$ & I & & & & & & I & \\
\hline 20. Pomolobus chrysochloris & .. & & 5 & 5 & Io & 3 & & & $\cdots$ & & IS & 8 \\
\hline 27. Dorosoma cepedianum. & & & & $\cdots$ & 1 & & & & Is & & I6 & \\
\hline 22. Esox vermiculatus... & & & & $\ldots \ldots$ & I & & & & $\mathrm{I}$ & & 2 & \\
\hline 23. Anguilla chrisypa & $\cdots$ & & I & (....... & 2 & & & & & & 3 & \\
\hline 24. Pomoxis sparoides... & 7 & $I$ & & $\ldots \ldots$ & 104 & & 144 & & 3 & & 258 & I \\
\hline 25. Pomoxis annularis.. & $3^{\circ}$ & $s$ & 195 & & 640 & $\mathbf{I}$ & 278 & 3 & 13 & & $x, 155$ & 9 \\
\hline 26. Ambloplites rupestris & & & & & & & $\mathbf{I}$ & & $\mathbf{I}$ & & 2 & \\
\hline 27. Apomotis cyanellus... & 41 & I & $=$ & & Io & & $x$ & & 4 & & 58 & I \\
\hline 23. Apomotis symmetricus $\ldots \ldots$. & I & & & & & & & & & & I & \\
\hline 29. Lepomis humilis.... & 42 & I & & & & & $\cdots$ & & $\mathbf{I}$ & & 43 & I \\
\hline 30. Lepornis pallidus. . & 35 & 4 & 30 & & 137 & …... & 43 & & ... & & 245 & 4 \\
\hline 3r. Eupomotis gibbosu & .. & $\cdots \cdots$ & 3 & & & & I & & & & 4 & $\cdots \cdots$ \\
\hline 32. Micropterus dolomieu & .. & & & (....... & 3 & & & & I & & 4 & \\
\hline 33. Micropterus salmoides & $\cdots$ & & 9 & & 9 & & 4 & & & & 22 & \\
\hline 34. Stizostedion vitreu & ... & & & & & & 3 & & 6 & & 9 & \\
\hline 35. Stizostedion canadense & 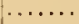 & & 5 & .. & 20 & & 32 & 1 & 38 & 2 & 95 & 3 \\
\hline 36. Rocel & & & 2 & ….... & II & $\mathbf{I}$ & 76 & & 3 & & 92 & I \\
\hline 37. Morone intern & ... & ........ & 3 & & 4 & & & & 75 & & 78 & \\
\hline 38. Aplodinotus grunniens. & 30 & $\cdots \cdots$ & $14 \mathbf{I}$ & 6 & 27 & & 104 & 5 & 20 & 4 & 322 & 15 \\
\hline Total.. & 210 & $I_{3}$ & 499 & II & 1.077 & 5 & 792 & so & 237 & 7 & $2,8 \pi 5$ & 46 \\
\hline
\end{tabular}

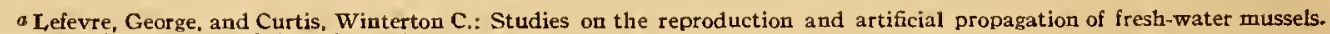
Butletin of the Bureau of Fisheries, vol. Xxx, p. Is9. 
NATURAL HOSTS OF FRESH-WATER MUSSELS.

TABLE VI.-NATURAL, HOStS OF FRESh-WATER MUSSELS.

\begin{tabular}{|c|c|c|c|c|c|c|c|c|c|c|c|c|c|c|c|c|}
\hline \multirow[b]{2}{*}{ Species of fish. } & \multicolumn{16}{|c|}{ Species of mussel and number of fish infected. } \\
\hline & 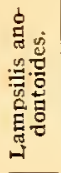 & 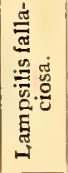 & 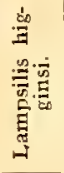 & 紫 & 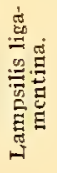 & 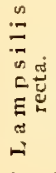 & 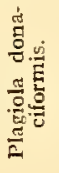 & 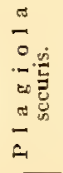 & 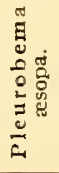 & 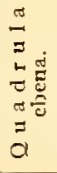 & 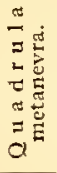 & 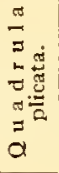 & 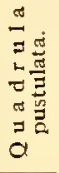 & 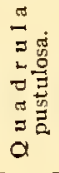 & 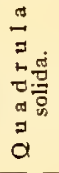 & 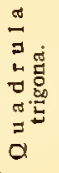 \\
\hline \multicolumn{17}{|l|}{$\begin{array}{l}\text { Scaphirhynchus plato- } \\
\text { rhynchus........... } \\
\text { Ameiurus natalis...... }\end{array}$} \\
\hline \multicolumn{17}{|l|}{$\begin{array}{l}\text { Pomolobus chrysocblo- } \\
\text { ris........................ }\end{array}$} \\
\hline Pomoxis sparoides. & I & & & & & & & & & & & & & & & I \\
\hline Pomoxis annularis . & 2 & I & & & & & & & & & & I & $\mathbf{1}$ & I & & \\
\hline $\begin{array}{l}\text { Apomotis cyanellus } \\
\text { Lepomis pallidus... }\end{array}$ & I & & & & & & & & & & $\begin{array}{l}1 \\
5\end{array}$ & & & & 2 & \\
\hline Lepomis pamiaus..... & I & & & & & & & & & & & & $\cdots$ & & & \\
\hline Stizostedion canadense. & & & I & & & & I & $\mathbf{I}$ & I & & & 1 & … & & $\cdots$ & .... \\
\hline Roccus chrysops. . . . . & & & & $\cdots$ & I & & & & & & & & ….. & & 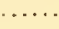 & $\ldots$ \\
\hline Aplodinotus grunniens & & & & 10 & & & 9 & & & & & & & & & \\
\hline
\end{tabular}

Note--A nodonta corpulenta has been found but once, a young Pomolobus chrysochloris carrying a few on the fins; being an external parasite, jt is not included in this table. A meiurus natalis is included in the table because it was found to harbor one
glocbidium, tbe species of which was, bowever, indeterminable. 


\section{EXPLANATION OF PLATES.}

\section{Plate XXIX.}

FIG. I. Glochidium of slop bucket, Anodonta corpulenta, on caudal fin of a young skipjack, Pomolobus chrysochloris.

FrG. 2. Young paper shell, Lampsilis levissima, on gill of sheepshead, Aplodinotus grunniens (side view) in an early stage of development.

FIG. 3. Postero- or antero-ventral view of young leevissima of about the same development as figure 2.

Fig. 4-5. Another stage of development of lavissima, figure 4 representing side and figure 5 dorsal views.

FIG. 6-7. Side and dorsal aspects of leevissima upon reaching what is considered its greatest development as a parasite.

\section{Plate XXX.}

Fig. 8. Postero-dorsal view of young deer-toe, Plagiola donaciformis, on gill of sheepshead, Aplodinotus grunniens.

FIG. 9. Side view of donaciformis on gills, the metamorphosis about completed.

FIG. Io. Portion of gill of Aplodinotus with young donaciformis in situ.

FIG. II. Glochidium of niggerhead, Q. ebena, on gill filament of skipjack, Pomolobus chryoschloris, taken August 13.

FIG. I2. Dorsal and ventral views of ebene of same relative age as figure II.

\section{Plate XXXI.}

Fig. I3. Quadrula ebena presumed to have about completed its metamorphosis; a specimen taken September 23, I9I2.

FIG. 14. Distal third of gill filament with glochidia of ebena in position.

FIG. I5. Glochidium of Quadrula metanevra on gill filament of sunfish, Lepomis pallidus.

FiG. 16. Glochidium of Quadrula plicata on gill filament of sauger, Stizostedion canadense.

FIG. 17. Glochidium of Pleurobema cesopa on gill filament of the sauger (S. canadense).

FIG. I8. Young ebena on gill filament, showing shifted position. 
BULL. U. S. B. F., IgI 2.

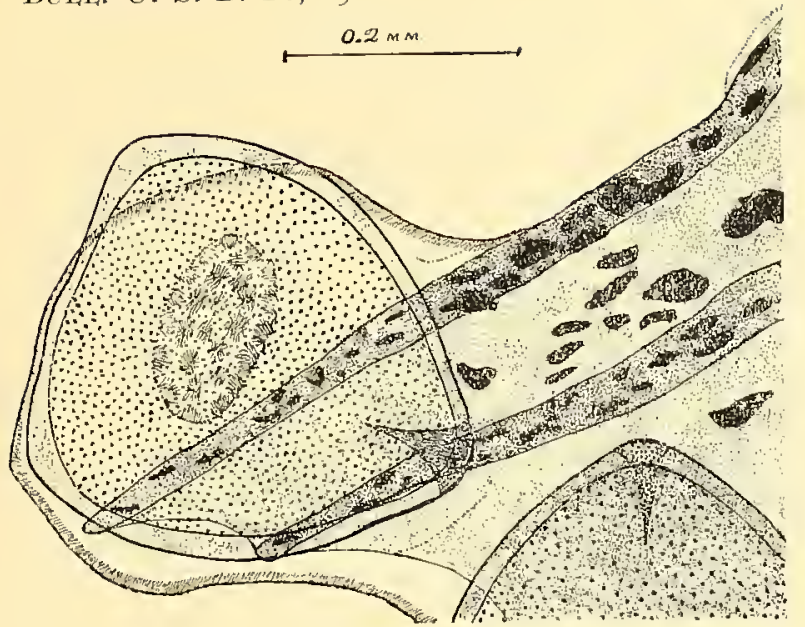

FIG. I.
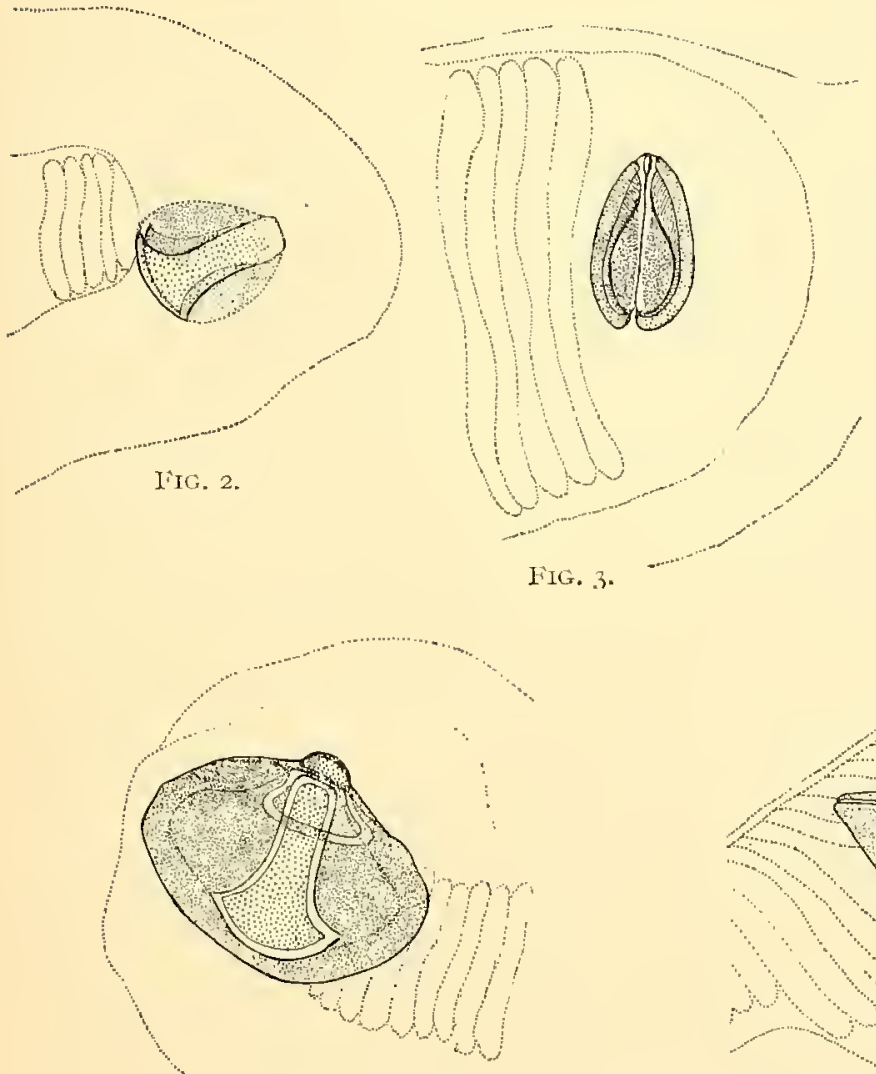

FIG. 6.

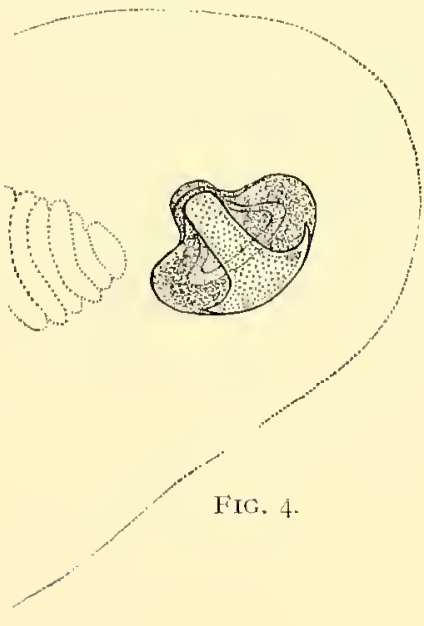

PLATE XXIX.
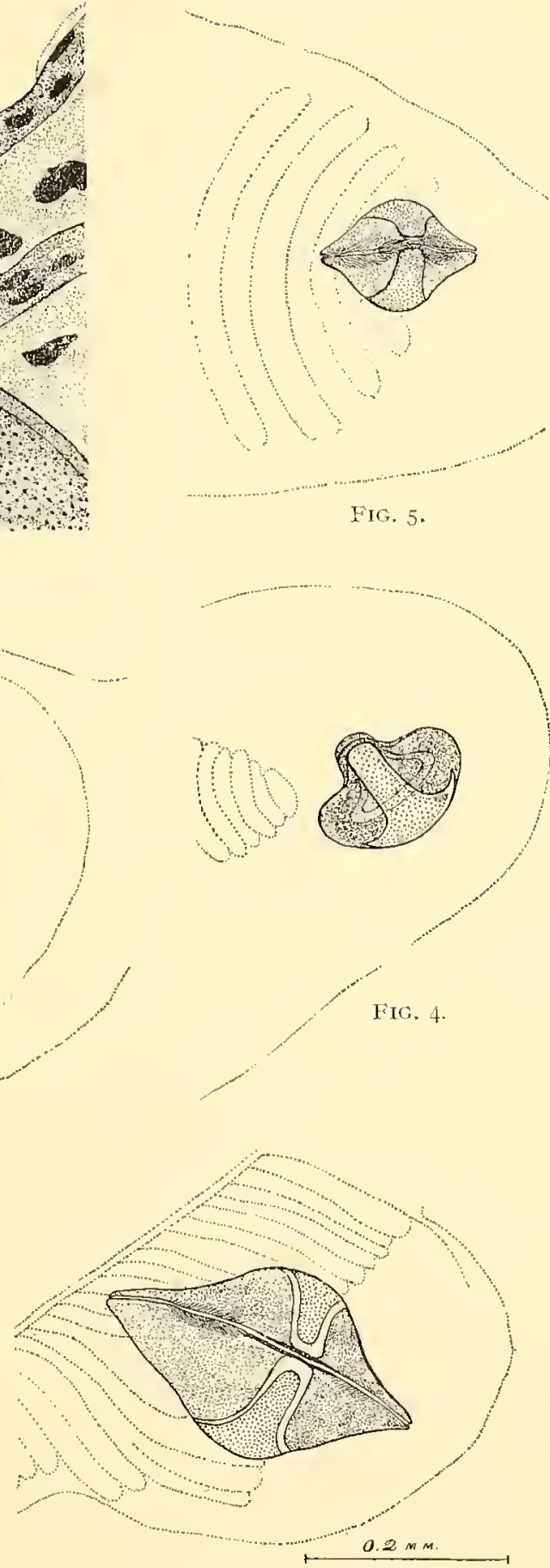

FIG. 7. 

BULL. U. S. B. F., II.

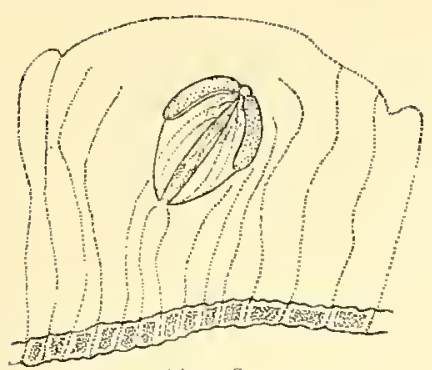

FIG. S,
PLATE XXX.
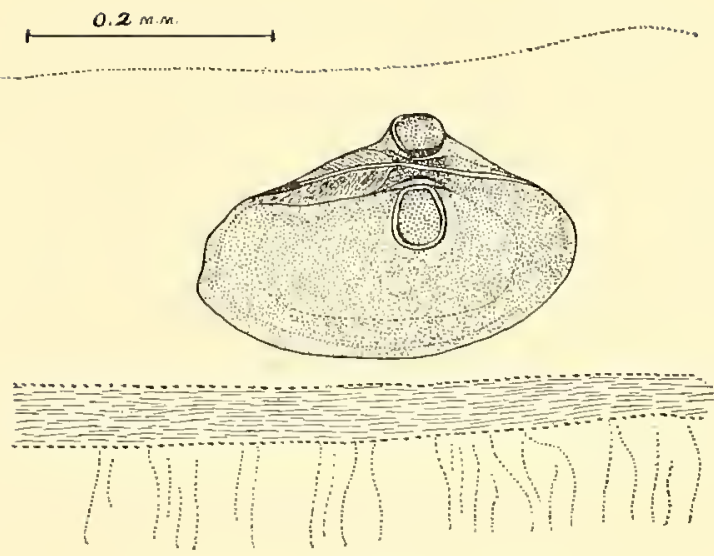

Fir. 9.

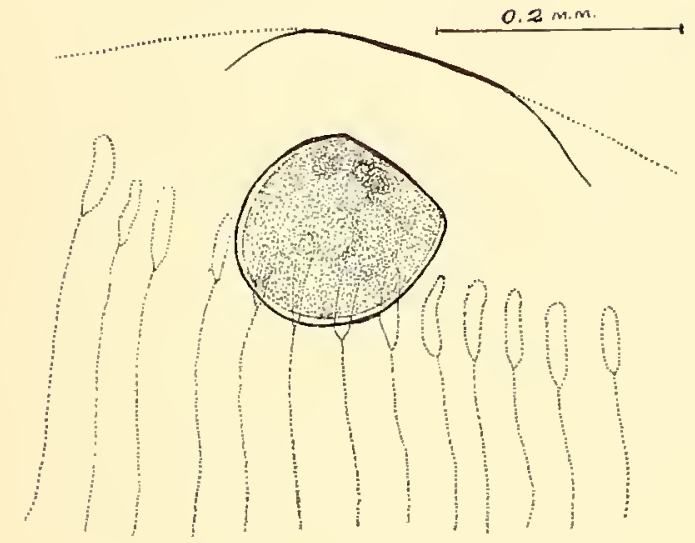

FIG. II.

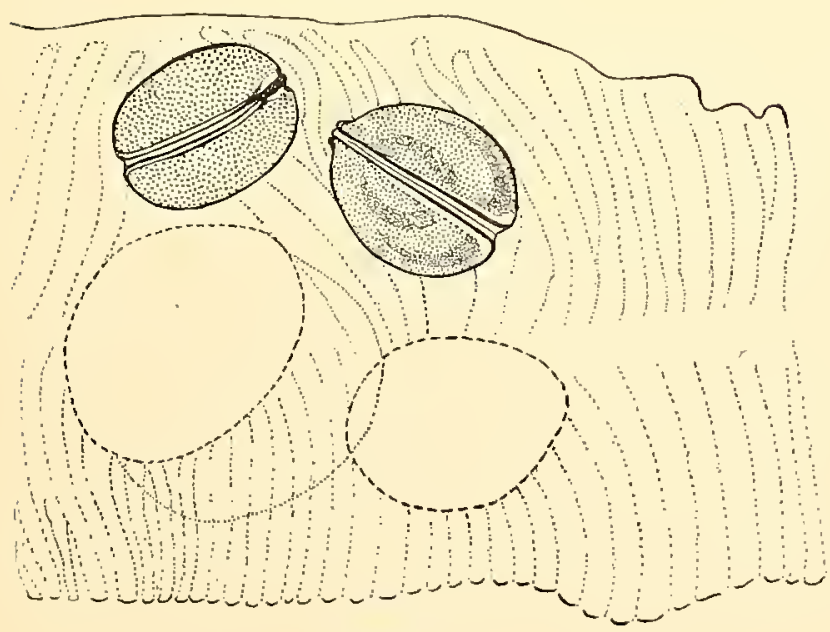

FIG. 12.

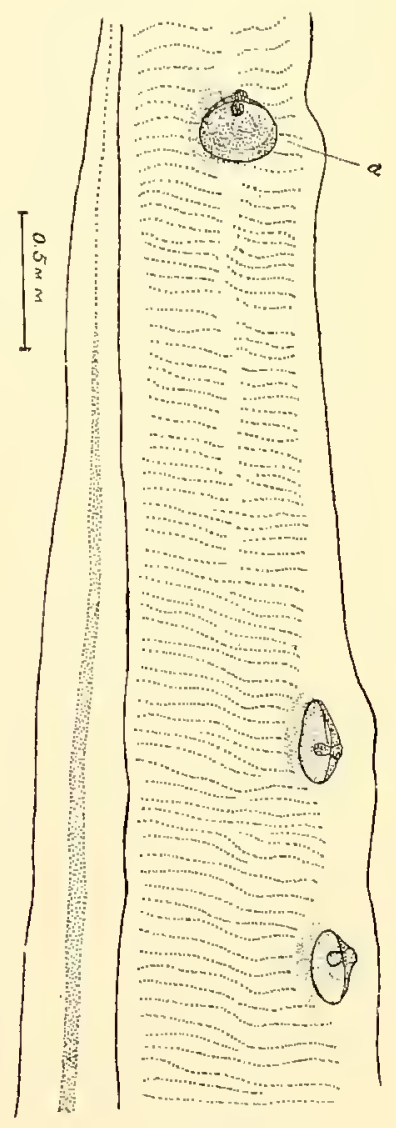

FIG. Io. 

Bult. U. S. B. F., I9I 2.

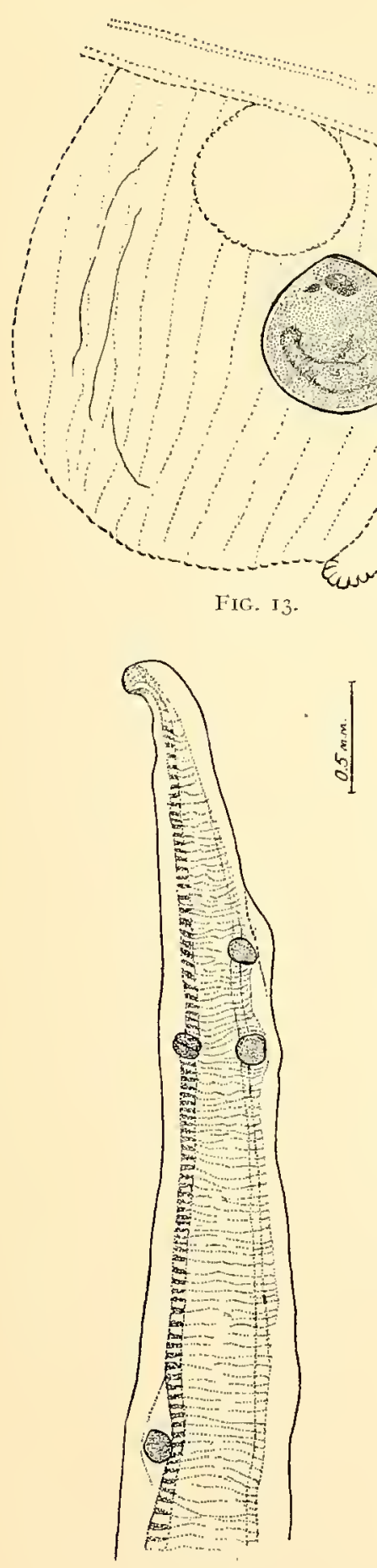

FIG. I 4.
PLATE NTIT.
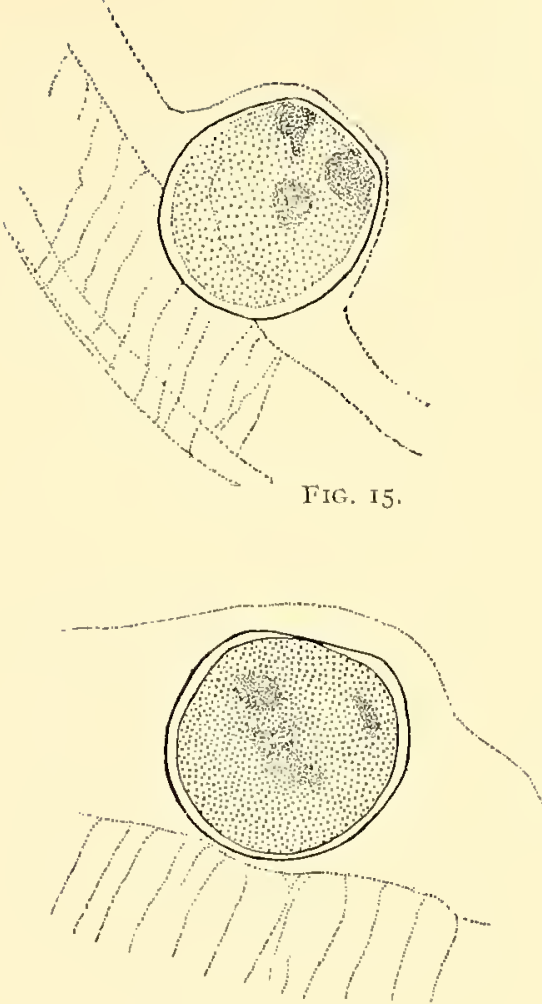

FIG. 17.

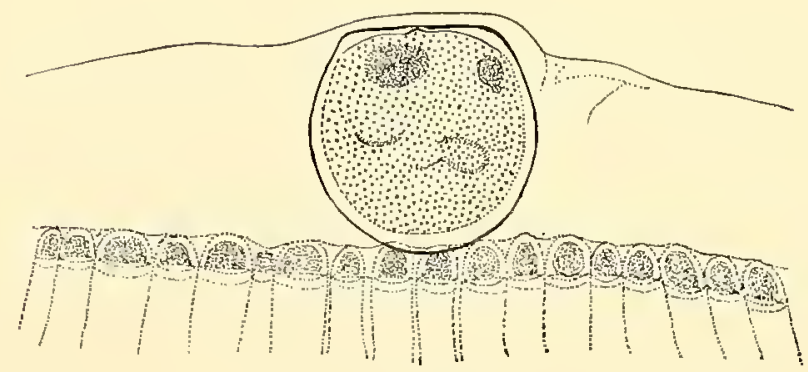

Fig, 16.

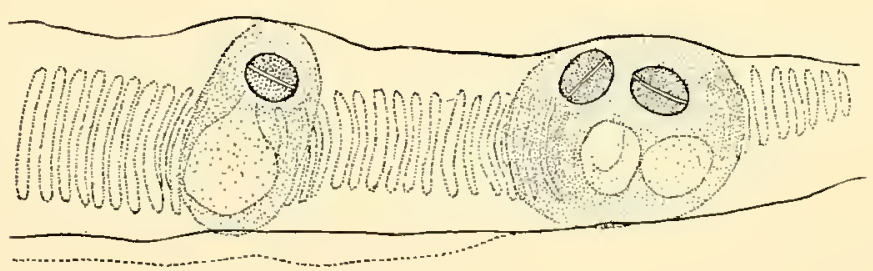

FIG. I8. 


$$
\text { • }
$$



